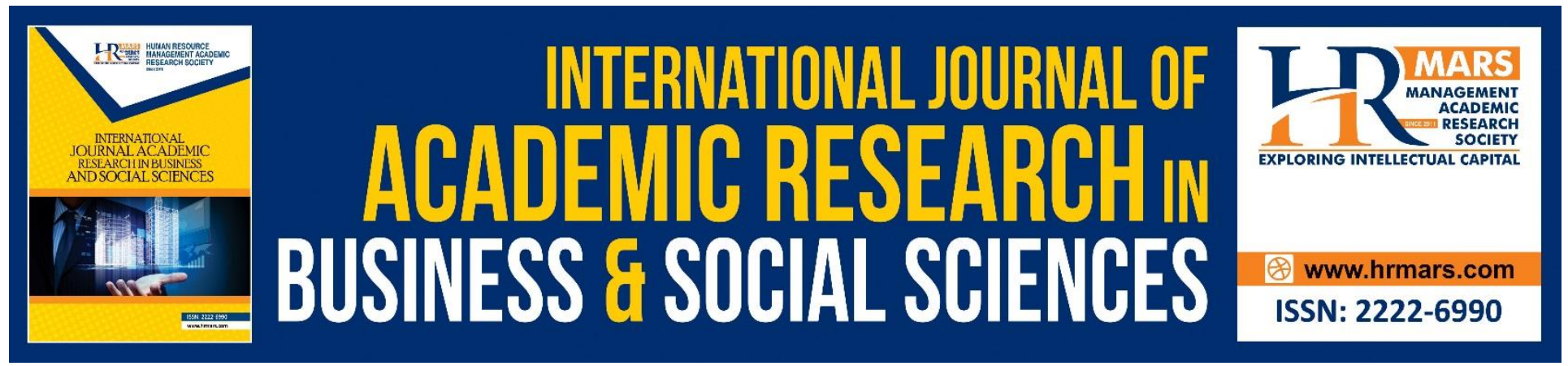

\title{
A Systematic Literature Review and Meta-Analysis of Medical Health Insurance and Takaful: Evidence from Malaysia
}

\begin{abstract}
Nahidah Mustafa, Fauzilah Salleh, Asyraf Afthanorhan, Wan Norhayate Wan Daud, Ahmad Shukri Yazid, Norfadzilah Rashid
\end{abstract}

To Link this Article: http://dx.doi.org/10.6007/IJARBSS/v9-i1/5811

DOI: $10.6007 /$ IJARBSS/v9-i1/5811

Received: 10 Dec 2018, Revised: 24 Dec 2019, Accepted: 3 Jan 2019

Published Online: 22 Jan 2019

In-Text Citation: (Mustafa et al., 2019)

To Cite this Article: Mustafa, N., Salleh, F., Afthanorhan, A., Daud, W. N. W., Yazid, A. S., \& Rashid, N. (2019). A Systematic Literature Review and Meta-Analysis of Medical Health Insurance and Takaful: Evidence from Malaysia. International Journal of Academic Research Business and Social Sciences, 9(1), 1266-1282.

Copyright: (C) 2019 The Author(s)

Published by Human Resource Management Academic Research Society (www.hrmars.com)

This article is published under the Creative Commons Attribution (CC BY 4.0) license. Anyone may reproduce, distribute, translate and create derivative works of this article (for both commercial and non-commercial purposes), subject to full attribution to the original publication and authors. The full terms of this license may be seen

at: http://creativecommons.org/licences/by/4.0/legalcode

Vol. 9, No. 1, 2019, Pg. 1266 - 1282

http://hrmars.com/index.php/pages/detail/IJARBSS

JOURNAL HOMEPAGE

Full Terms \& Conditions of access and use can be found at http://hrmars.com/index.php/pages/detail/publication-ethics 


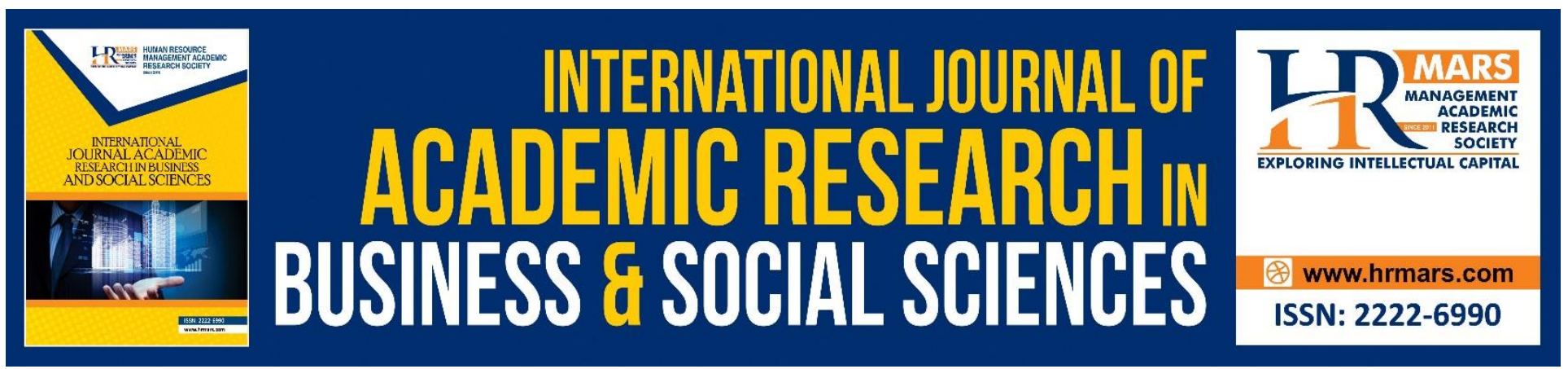

\title{
A Systematic Literature Review and Meta-Analysis of Medical Health Insurance and Takaful: Evidence from Malaysia
}

\author{
Nahidah Mustafa, Fauzilah Salleh, Asyraf Afthanorhan, Wan \\ Norhayate Wan Daud, *Ahmad Shukri Yazid, Norfadzilah Rashid \\ Faculty of Economic and Management Science, Universiti Sultan Zainal Abidin, \\ 21300 Kuala Nerus, Terengganu. Malaysia. \\ *Corresponding author: shukri@unisza.edu.my
}

\begin{abstract}
Medical and health takaful is the protection given to cover the cost of private medical treatment including the hospitalization, surgery, and treatment, diagnosed with certain illnesses or are involved in an accident. The purpose of this research is to identify and determine the demand for Medical Health Insurance and Takaful in Malaysia. Researchers want to identify the factors that Effect Medical Health Insurance and Takaful demand in Malaysia. The researcher wants to find what Effect Medical Health Insurance and Takaful among the public. In this research, the researcher used 55 articles from the year 2007 until 2017 that related to the effect of Medical Health Insurance and Takaful using Preferred Reporting Items for Systematic Reviews and Meta-Analysis (PRISMA) approach. 84\% of the articles used a quantitative method where the rest using the qualitative method to collect the data. The researcher found that 14 of the article were stating about the factor that Effects the Medical Health Insurance and Takaful demand. The expected finding was classified into percentage based on the result of the article where a demographic factor is $42 \%$, education factor $21 \%$ and price (income) factor $37 \%$. To improve the research findings, this study uses random-effect model to provide the forest plot result and it was found the demographic (gender and age), education and price are highly significant associated with the Medical Health Insurance and Takaful. Therefore, it is essential to increase the public awareness about the importance of having Medical Health Insurance and Takaful. Keyword: Medical and Health Insurance, Health Takaful, Demand, Malaysia, PRISMA, Meta-Analysis
\end{abstract}

\section{Introduction}

The improvement of Takaful industry in Malaysia additionally joining the Islamic bank operation which was form in the year 1983. Takaful is demonstrated as the answer to the issue life insurance 
prohibited by the Malaysian National Fatwa Community. The people group issued an announcement about the live coverage that it is as a void contract due to the presence of the components of Riba' (usury), Maisir (Gambling), Gharar (vulnerability). The legislature of Malaysia builds up a Special Task Force in 1982 to observe the command to set up an Islamic-based insurance agency.

Based on statistics from the World Health Organization (2013), total expenditure for per capita healthcare in Malaysia has increased by USD 99.2 from USD 283.6 in 2009 to USD 382.8 in 2011 (Afthanorhan, Awang, \& Fazella, 2017b). However, the percentage the amount of expenditure on healthcare in the public health system has experienced a decrease of $3.8 \%$, from $59 \%$ in 2009 to $55.2 \%$ in the year 2011. In contrast, the percentage of total expenditure on healthcare in the health system private sector is on the rise, which is up 3.8\% from $41 \%$ in the year 2009 to $44.8 \%$ in 2011 . This shows that society is growing depending on the personal health system compared to the public health system.

One of the reasons why this is happening is the public health system requires longer waiting periods for receiving treatment. This modern society is very concerned with healthcare and realizes that the opportunity to return to health is higher if you receive treatment as soon as possible as possible, the probability of death can be reduced. Senior Consultant Pediatric, Hematologist and Pediatric Oncology, Dr. Hishamshah Mohd Ibrahim said that as early as cancer patients receive treatment, the higher the chances of recovery (Zaitie, 2013; Awang et al., 2015). For example, a chance to recover for cancerous cancer at stage 1 treated is between $90 \%$ and $95 \%$ while the opportunity to cure for the patient's cancer breast in the four stages treated is only 15\% (Kurniawati 2011). Hence, many people will choose the private health system to seek the best possible treatment although the cost of private health spending is more expensive.

Expensive medical costs it would definitely be a burden on society, especially for the lower income group and simple. This situation will be worse when the Ministry of Health has been allowing increased private healthcare medical expenses by $14.4 \%$ on lately (Azura, 2014; Afthanorhan, Awang, \& Fazella, 2017a). In order to reduce the burden to finance medical expenses, society can buy medical and health insurance to guarantee medical expenses. They can be financed by medical and health insurance in the future. The research intends to identify the level of consumer demand for ownership insurance medical and health. In addition, the factors that drive consumer demand to buy medical and health insurance will also be reviewed.

\section{Literature Review}

The concept of insurance in preparation for an uncertain future goes well with a saying of "Dig the well before you are thirsty." An imbalance of life and challenges to the problem health causes that are individuals need to make early preparation for to ensure them take the opportunity to acquired best health services. There are still some Malaysian who is still not aware that medical and health insurance is a policy that covers the cost of private medical care that may be expensive such as hospitalization and surgical costs.

Through the Medical Health Insurance and Takaful, the burden of the cost of treatment and other medical expenses due to disability and chronic illness will be transferred to the insurance and takaful company or also known as an insurer (Htay, Sadzali, \& Amin, 2014). Communities need to understand that there are several factors that cause Medical Health Insurance and Takaful as important today. 
INTERNATIONAL JOURNAL OF ACADEMIC RESEARCH IN BUSINESS AND SOCIAL SCIENCES Vol. 9, No. 1, Jan, 2019, E-ISSN: 2222-6990 @ 2019 HRMARS

First, health care costs are increasingly expensive and these costs include the cost of consulting doctors, nurses, medicines, medical equipment, and buildings. Medical costs will continue to increase in the future due to inflation. Second, the number of cases of chronic diseases in Malaysia is high. Although medical technology is progressing, the number of sufferers for chronic diseases has also increased (Husniyah, Norhasmah, \& Amim, 2017).

This research paper is focusing on the factors Effecting the demand for Medical Health Insurance and Takaful among the public in Malaysia. Based on the searching in the academic database using a journal, the researcher list all factors that Effect the demand for Medical Health Insurance and Takaful among the public in Malaysia. The researcher collected all information and fact of the selected journal. They are several factors that Effect the demand for Medical Health Insurance and Takaful among the public in Malaysia.

The demography factors influence the demand for Medical Health Insurance and Takaful among the public. Emamgholipour (2016) highlighted that the demography factor such as the age, gender, income, and education level have a positive relationship with the demand for Medical Health Insurance and Takaful. According to Deloitte (2011), non-buyer respondent stated that they haven't purchased the coverage because they have not understood well about the need for life insurance. In accordance to Ulbinate, Kucinkiene, \& Moullec (2013), the researcher found that there is a positive relationship between social influence and health life insurance demand. Peer effect, family, insurance agent is part of social influence. The price also can be a determining factor of demand for Medical Health Insurance and Takaful among the public. The high price of insurance and even the premium will decrease the demands of Medical Health Insurance and Takaful.

Emamgholipour (2016) analyzed the data from the 2013 Household Income and Expenditure Survey of the Statistical Center of Iran (SCI). The research is being carried out ethically by the households that take part in this survey had been informed by a researcher. The date from $\mathrm{SCl}$ was collected using the sample from questionnaires which is reliable and valid. The data collected were then used in the econometric and statistical analysis. A total of 7454 rural households and 5561 urban households participated in the research to identify the factors that influence the demand for private health insurance.

Kansra (2015) reported that the total sample of 200 women (50 from each group) was selected as per convenience approach. The primary data was collected using a structured questionnaire. The questionnaire deals with the necessary information of the respondent, awareness of health insurance and various sources of awareness. Based on the determinants of awareness of health insurance in the factor of demographic, it indicates that the age was positively associated with awareness of health insurance.

According to Sheila et al. (2015), the lower-income group in Malaysia is the sample in this research. Selected Sampling was applied for interview approach. According to Sekaran and Bougie (2010), an interview is a useful data collection method, especially during the exploratory stages as the objective of this research is to study the status and seek insight into the Takaful industry. The interviews also help the researcher to gather valid information that is relevant to the research questions and objectives. Types of interviews used were semi-structured interviews. The primary criteria of respondents' selection are to study which factor that Effect the demand for medical health Insurance and Takaful in Malaysia. 
In the context of these researches, most of the study of the article is focused on an interview survey. The research focused factor that Effects the demand for medical health Insurance and Takaful in Malaysia. The majority of the authors were used quantitative research method to collect and analyze the data. As a result, a quantitative method allows the authors to collect the data more accurately by an interview the respondent.

Although there are many factors that Effect the demand for Medical Health Insurance and Takaful, the researcher decided to only focus on the major factor which is demographic, price and education factor as addressed in Figure 1. A researcher found out that the three-factor plays an important role in the demand for Medical Health Insurance and Takaful among the public in Malaysia.

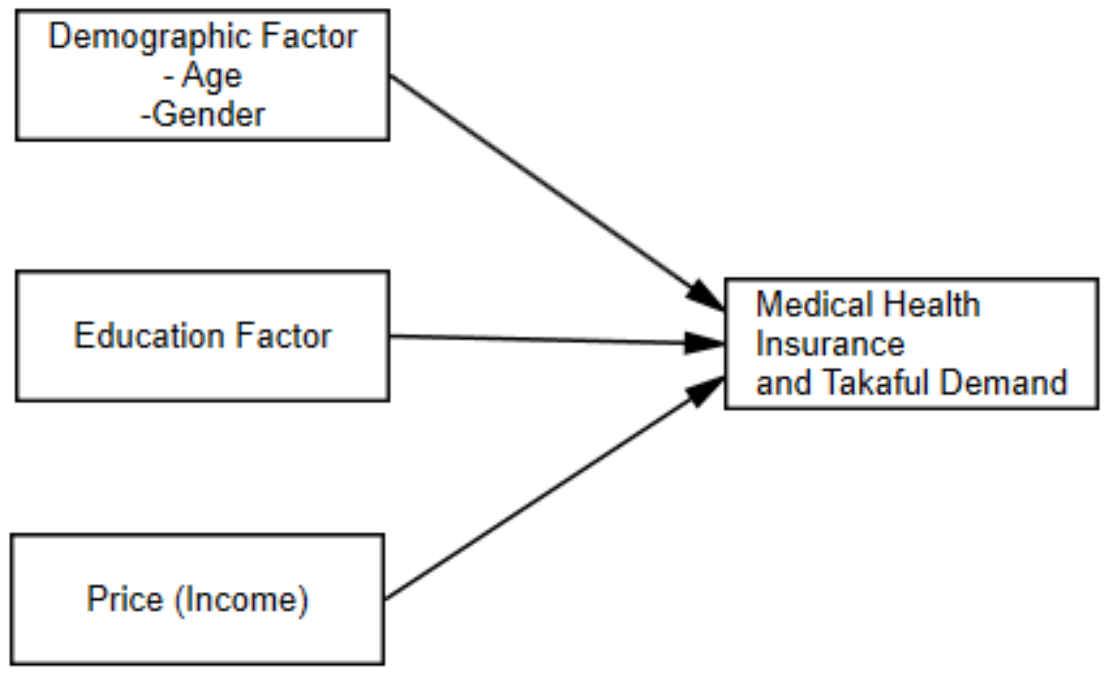

Figure 1: Research Framework

\section{Data Source and Searches}

A literature was performed to identify and examine prior studies published from January 2007 up to March 10, 2018 using the electronic databases Scopus, Google Scholar and Excellence Research in Australia (ERA). For Google Scholar, the following search terms were used: medical health insurance [All fields], medical health promotion [All fields], medical healthcare [All field], medical health information [All field], health insurance coverage [All field], takaful [All field], and rand for medical care [All field].

The literature search investigating the association between medical health insurance and Takaful among the public was based on published meta-analysis using Scopus and ERA as an additional databases and was updated to include recent studies published up to March 2018. Those search strategies had no language restrictions and most of the recent studies published are from Malaysia. Moreover, the list of reference from retrieved research papers were being examined to seek further relevant studies. Literature searches were conducted by the first and second author, with questions or uncertainties resolved by consent with the rest authors. 
INTERNATIONAL JOURNAL OF ACADEMIC RESEARCH IN BUSINESS AND SOCIAL SCIENCES

Vol. 9, No. 1, Jan, 2019, E-ISSN: 2222-6990 @ 2019 HRMARS

\section{Methods}

The meta-analysis is a prominent statistical procedure for analyzing the combined data from different research studies, and can be a great source of concise up-to-date information (Nakagawa et al. 2017). This method was developed for forty decades that was actually introduced for medical area where human and animals are the main species of interest. In the next two decades, the meta-analysis has penetrated different areas of biological sciences, ecology, physiology, ecosystems or even chemotherapy. Meta-analysis not only provide quantitative information (such as fixed and random effects, beta coefficients, wald test, heterogeneity results and consistency among studies) but also valuable for qualitative information through current knowledge gaps. The benefits of this method has attracted other applied researchers whose interest on those strategies in handling the empirical research. As such, their benefits also have been rapidly increasing in other areas including psychology (Protogerou, Johnson, \& Hagger, 2018; Kooij et al., 2018), quality of life (Ngamba, Panagioti, \& Armitage, 2017), education (Fan et al., 2017), human research management (Tzabbar, Tzafrir, \& Baruch, 2017; Ones, Viswesvaran \& Schmidt, 2017) and marketing research (Kim \& Peterson, 2017). For this study, the meta-analysis was performed by combining the multiple variables of interest (e.g: age, gender, price, and education) for assessing their effect on medical health insurance and takaful demands across 14 studies based on random-effects using Restricted Maximum Likelihood method (REML). The random-effects was used because the outcomes of this study is very rare and heterogeneity modeling was deemed important in determining the behavior of the study (Hedges \& Olkins, 1985; Guolo \& Varin, 2017; Heck, Gronau, \& Wagenmakers, 2017). According to Viechtbauer (2010), there are eight estimators is offered to specify the desired model such as Full Information Maximum Likelihood (FIML), Restricted ML (REML), DerSimonian-Laird, Hedges, Hunter-Schmidt, Sidik-Jonkman, Empirical Bayes, and Paule-Mandel. Accordingly, the REML method is known as the best estimator in model specification due to their unbiasedness and efficiencies as also applied in the current study.

To evaluate the weighting of each study, the standard error and effect size were calculated using $2 \mathrm{x}$ 2 frequency table to produce Odds-Ratio (OR) and Risk Ratio (RR). Then, the heterogeneity, measures of fit, funnel plots, forest plots, and descriptive analysis were performed. The commands for conducting meta-analysis are available in the $\mathrm{R}$ package metafor which includes functions for fitting the meta-analytic fixed and random-effects models (Viechtbauer, 2010). The systematic literature review was conducted according to Preferred Reporting Items for Systematic Reviews and MetaAnalysis (PRISMA) approach and Cochrane Handbook recommendations (Higgins \& Green, 2011) and the quantitative analysis is performed using $\mathrm{R}$ package.

\section{Results}

The detailed steps of the meta-analysis research search and selection process are given as an adapted PRISMA flow diagram as is shown in Figure 2. Overall, 226 reports were identified through Scopus, Google Scholar, ERA and other sources from 2007 to March 10, 2018 in the updated meta-analysis. However, only 55 reports (25.46\%) were identified relevant to the scope of the study that is associated with the medical insurance and takaful among the public. Therefore, the rest of the reports $(74.54 \%)$ were excluded from this study as it were not reached the conformity assessment procedure by checking the title and mechanism study. Then, 55 report were re-screened to identify 
INTERNATIONAL JOURNAL OF ACADEMIC RESEARCH IN BUSINESS AND SOCIAL SCIENCES

Vol. 9, No. 1, Jan, 2019, E-ISSN: 2222-6990 @ 2019 HRMARS

the factors underlying on each studies. Based on 55 reports with careful examination, 14 reports were identified similar with the factors addressed in this study. In other words, 41 report were not focused on important factors towards medical health insurance and takaful demand. From 14 reports, 12 reports (84\%) were conducted using quantitative approach and other two reports (16\%) were analyzed by the qualitative approach.

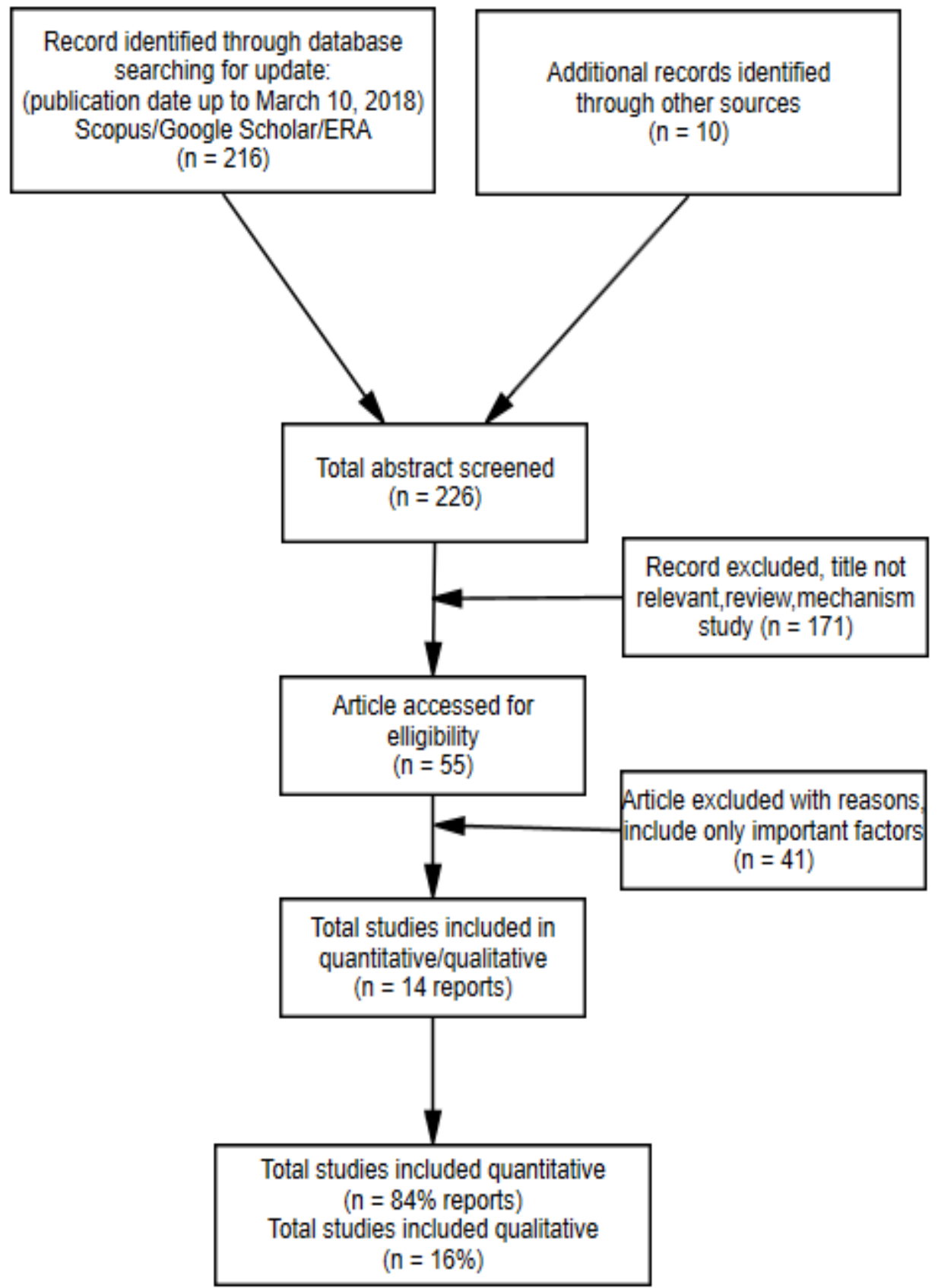

Figure 2: Flowchart for the article selection process for a meta-analysis of the Effect Medical Health Insurance and Takaful in Malaysia 
INTERNATIONAL JOURNAL OF ACADEMIC RESEARCH IN BUSINESS AND SOCIAL SCIENCES

Vol. 9, No. 1, Jan, 2019, E-ISSN: 2222-6990 @ 2019 HRMARS

Summary of the studies selected for analysis

\begin{tabular}{|c|c|c|c|c|c|}
\hline \multirow[t]{2}{*}{ Author (Year) } & \multirow{2}{*}{$\begin{array}{l}\text { Sample } \\
\text { Size }\end{array}$} & \multicolumn{2}{|c|}{ Demographic } & \multirow[t]{2}{*}{ Education } & \multirow{2}{*}{$\begin{array}{l}\text { Price } \\
\text { (Income) }\end{array}$} \\
\hline & & Age & Gender & & \\
\hline $\begin{array}{l}\text { Ayimbillah Atinga } \\
(2011)\end{array}$ & 250 & $\begin{array}{l}18-70 \\
\text { years }\end{array}$ & $\begin{array}{l}\text { There was } \\
\text { significant } \\
\text { different } \\
\text { between male } \\
\text { and female }\end{array}$ & $\begin{array}{l}\text { Most of the } \\
\text { respondent did } \\
\text { not have formal } \\
\text { education }\end{array}$ & $\begin{array}{l}\text { Unemployed } \\
\text { and have no } \\
\text { concrete } \\
\text { source of } \\
\text { income }\end{array}$ \\
\hline $\begin{array}{l}\text { Tanko, Harun, } \\
\text { Gorondutse, \& Salihu } \\
(2015)\end{array}$ & 583 & $\begin{array}{l}19-35 \\
\text { years }\end{array}$ & $\begin{array}{l}\text { Male head } \\
\text { household is } \\
\text { higher than } \\
\text { female }\end{array}$ & $\begin{array}{l}\text { High education } \\
\text { leads to high } \\
\text { awareness } \\
\text { about the } \\
\text { health } \\
\text { insurance }\end{array}$ & $\begin{array}{l}\text { Insurance } \\
\text { fees should } \\
\text { be } \\
\text { considered } \\
\text { for the low- } \\
\text { income } \\
\text { families }\end{array}$ \\
\hline $\begin{array}{l}\text { Nsiah-Boateng } \quad \& \\
\text { Aikins (2013) }\end{array}$ & 376 & $\begin{array}{l}18-69 \\
\text { years }\end{array}$ & Not available & $\begin{array}{l}\text { Education } \\
\text { would be useful } \\
\text { to sensitize } \\
\text { people on the } \\
\text { role that helath } \\
\text { insurance plays } \\
\text { in stabilizing } \\
\text { their situation }\end{array}$ & $\begin{array}{l}\text { Many low- } \\
\text { income } \\
\text { families are } \\
\text { challenged } \\
\text { with how to } \\
\text { finance their } \\
\text { health care }\end{array}$ \\
\hline $\begin{array}{l}\text { Kansra \& Pathania } \\
(2012)\end{array}$ & 200 & $\begin{array}{l}25-55 \\
\text { years }\end{array}$ & $\begin{array}{l}\text { There has } \\
\text { significant } \\
\text { relation } \\
\text { between } \\
\text { gender and } \\
\text { awareness } \\
\text { about health } \\
\text { insurance }\end{array}$ & $\begin{array}{l}\text { Education is } \\
\text { positively } \\
\text { related } \\
\text { healthcare } \\
\text { insurance }\end{array}$ & $\begin{array}{l}\text { The main } \\
\text { factor } \\
\text { affecting the } \\
\text { decision to } \\
\text { purchase } \\
\text { health } \\
\text { insurance }\end{array}$ \\
\hline $\begin{array}{ll}\text { Sindecharak } & \& \\
\text { Prasarkul (2010) } & \end{array}$ & 21,829 & $\begin{array}{l}15 \text { and } \\
\text { over } \\
\text { years }\end{array}$ & $\begin{array}{l}\text { Females had } \\
\text { higher } \\
\text { proportion } \\
\text { than males } \\
\text { due to health } \\
\text { insurance and } \\
\text { cooperative } \\
\text { shares }\end{array}$ & $\begin{array}{l}\text { It was found } \\
\text { that } \\
\text { educational } \\
\text { attainment is } \\
\text { the most } \\
\text { concrete } \\
\text { predictors of } \\
\text { life insurance } \\
\text { consumption }\end{array}$ & $\begin{array}{l}\text { The results } \\
\text { indicate there } \\
\text { are significant } \\
\text { association } \\
\text { with different } \\
\text { factors } \\
\text { especially age } \\
\text { and income }\end{array}$ \\
\hline $\begin{array}{l}\text { Nu Htay, Sadzali, \& } \\
\text { Amin (2014) }\end{array}$ & 163 & $\begin{array}{l}\text { Not } \\
\text { available }\end{array}$ & $\begin{array}{l}\text { Male }=98 \\
\text { Female }=65\end{array}$ & $\begin{array}{l}\text { Poor education } \\
\text { avoided the }\end{array}$ & $\begin{array}{l}\text { Takaful } \\
\text { operators }\end{array}$ \\
\hline
\end{tabular}




\begin{tabular}{|c|c|c|c|c|c|}
\hline & & & & $\begin{array}{l}\text { benefits of } \\
\text { Takaful } \\
\text { operators }\end{array}$ & $\begin{array}{l}\text { concentrating } \\
\text { more on the } \\
\text { middle and } \\
\text { high income } \\
\text { groups but } \\
\text { many from } \\
\text { lower-income } \\
\text { group are } \\
\text { missing out } \\
\text { on its } \\
\text { benefits }\end{array}$ \\
\hline $\begin{array}{l}\text { Husniyah, Norhasmah, } \\
\text { \& Amim (2017) }\end{array}$ & 356 & $\begin{array}{l}20-59 \\
\text { years }\end{array}$ & $\begin{array}{l}\text { Male }=123 \\
\text { Female }=231\end{array}$ & $\begin{array}{lr}\text { Level of } \\
\text { education } \\
\text { among } \\
\text { influential } \\
\text { factors } \\
\text { affecting } \\
\text { increase } \\
\text { demand } \\
\text { health } \\
\text { insurance }\end{array}$ & $\begin{array}{l}\text { Income was } \\
\text { positively } \\
\text { correlated } \\
\text { with } \\
\text { insurance } \\
\text { coverage }\end{array}$ \\
\hline Abu-Bakar et al. (2016) & 14,223 & $\begin{array}{l}\text { Above } \\
18 \text { years }\end{array}$ & Not available & $\begin{array}{l}\text { Education is } \\
\text { either one of } \\
\text { the factor that } \\
\text { influence } \\
\text { utilization of } \\
\text { health services }\end{array}$ & $\begin{array}{l}\text { Those with } \\
\text { higher } \\
\text { income are } \\
\text { less likely to } \\
\text { access health } \\
\text { care }\end{array}$ \\
\hline Kefeli \& Jones (2012) & 29,690 & $\begin{array}{l}\text { Above } \\
21 \text { years }\end{array}$ & $\begin{array}{l}\text { Male and } \\
\text { females in the } \\
\text { age range } \\
\text { from } 21 \text { to } 46 \\
\text { are the most } \\
\text { prevent group } \\
\text { with health } \\
\text { insurance }\end{array}$ & \multicolumn{2}{|c|}{$\begin{array}{l}\text { The results show that taking up } \\
\text { health insurance is lower among } \\
\text { individuals with lower income } \\
\text { and lower level of education }\end{array}$} \\
\hline Rahim \& Amin (2011) & 176 & $\begin{array}{l}\text { Not } \\
\text { available }\end{array}$ & $\begin{array}{l}\text { Male }=49 \\
\text { Female }=127\end{array}$ & \multicolumn{2}{|c|}{$\begin{array}{l}\text { The study reported that the } \\
\text { indispensable factors affecting } \\
\text { the need for health insurance } \\
\text { were the education level of the } \\
\text { family head, the location, and } \\
\text { diversification of income } \\
\text { sources. }\end{array}$} \\
\hline
\end{tabular}


INTERNATIONAL JOURNAL OF ACADEMIC RESEARCH IN BUSINESS AND SOCIAL SCIENCES Vol. 9, No. 1, Jan, 2019, E-ISSN: 2222-6990 @ 2019 HRMARS

\begin{tabular}{|c|c|c|c|c|c|}
\hline $\begin{array}{l}\text { Bakar \& Samsudin } \\
(2016)\end{array}$ & 14,223 & \multicolumn{4}{|c|}{$\begin{array}{l}\text { Previous studies demonstrate that health care utilization } \\
\text { was influenced by socio-demographic factors such as } \\
\text { income, gender, marital status, household size and age } \\
\text { (Lopez-Nicolas, 1998; Deb et al., 2006; Nandakumar et al., } \\
\text { 2000). }\end{array}$} \\
\hline $\begin{array}{l}\text { Meslek, Icin, \& Talebi } \\
(2016)\end{array}$ & 13,015 & \multicolumn{4}{|c|}{$\begin{array}{l}\text { The results show that the coefficients of age, gender, } \\
\text { household size, income, and education were statistically } \\
\text { significant for both urban and rural households; however, } \\
\text { the coefficient of occupation was only statistically significant } \\
\text { for urban households. }\end{array}$} \\
\hline Hasan \& Kasule (2012) & $\begin{array}{l}\text { Not } \\
\text { available }\end{array}$ & $\begin{array}{l}\text { Not } \\
\text { available }\end{array}$ & $\begin{array}{l}\text { Health } \\
\text { insurance also } \\
\text { influenced by } \\
\text { age factor }\end{array}$ & $\begin{array}{l}\text { Insurance has a } \\
\text { double-edge } \\
\text { effects } \\
\text { depending on } \\
\text { education level }\end{array}$ & $\begin{array}{l}\text { Health } \\
\text { insurance } \\
\text { rate was } \\
\text { influenced by } \\
\text { income }\end{array}$ \\
\hline $\begin{array}{l}\text { Nosratnejad et al. } \\
(2017)\end{array}$ & 300 & & $\begin{array}{l}\text { Male and } \\
\text { female willing } \\
\text { to participate } \\
\text { health } \\
\text { insurance } \\
\text { scheme }\end{array}$ & $\begin{array}{l}\text { More than } 80 \\
\text { percent from } \\
\text { high education } \\
\text { level willing to } \\
\text { join the health } \\
\text { insurance } \\
\text { scheme }\end{array}$ & $\begin{array}{l}\text { There has } \\
\text { positive } \\
\text { relationship } \\
\text { between } \\
\text { income and } \\
\text { willingness to } \\
\text { pay for health } \\
\text { insurance }\end{array}$ \\
\hline
\end{tabular}

Table 1: Summary of the studies selected for analysis

\section{Descriptive Statistics}

In the previous years, there are many articles have been published relating to Medical Health Insurance and Takaful. After selecting 55 article about the Medical Health Insurance and Takaful, the researcher found that 14 of the article were stating about the factor that Effects the Medical Health Insurance and Takaful demand. From the study, the expected finding was classified into percentage based on the result of the article where the demographic factor is $42 \%$, education factor $21 \%$ and price (income) factor $37 \%$.

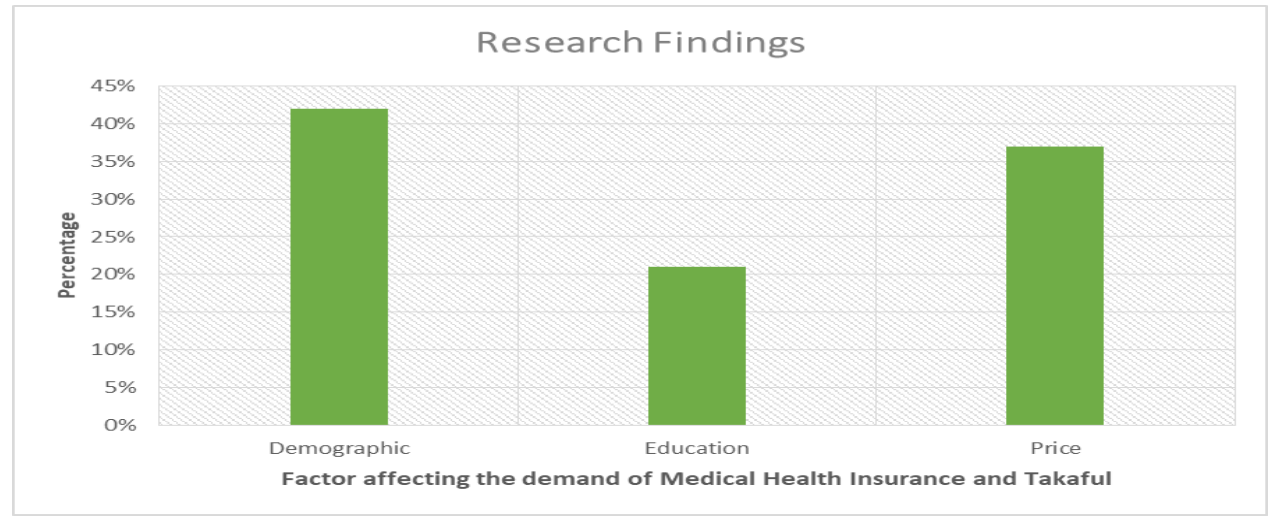


Figure 3: Descriptive Statistics for Demographic, Education, and Price Based on the research by Emamgholipour (2016), the findings show that the factors of age and income were found to be significant for the demand of Medical Health Insurance among the rural and urban households. However, the factor for occupation was only significant for urban households but not significant for rural households. According to the researcher, since single persons need to pay the premiums by themselves, the demand for health insurance is expected to increase among aged, educated and high-income people.

Education level and the demand for medical health insurance and Takaful have a positive relationship both rural and urban households. According to Kansra (2015), education was positively and significantly associated with the awareness of health insurance. Meanwhile, according to Nguyen \& Knowles (2010), a person with higher education are more expected to buy an insurance than those with lower education. A group of people with graduate education have the highest demand for medical health insurance and Takaful because they are considered as risk-averse meanwhile people with lower levels of education are high risk-takers.

According to the Fang et al. (2012), households with higher incomes were more likely to have private and public. Households with higher expenses had higher incomes and were more likely to be able to afford private insurance. While households with the presence of chronic diseases were more likely to have public and private health insurance coverage. In order to confirm with our findings, we used alternative method of random-effect model as depicted in Figure 4 and Figure 5. 
INTERNATIONAL JOURNAL OF ACADEMIC RESEARCH IN BUSINESS AND SOCIAL SCIENCES

Vol. 9, No. 1, Jan, 2019, E-ISSN: 2222-6990 @ 2019 HRMARS

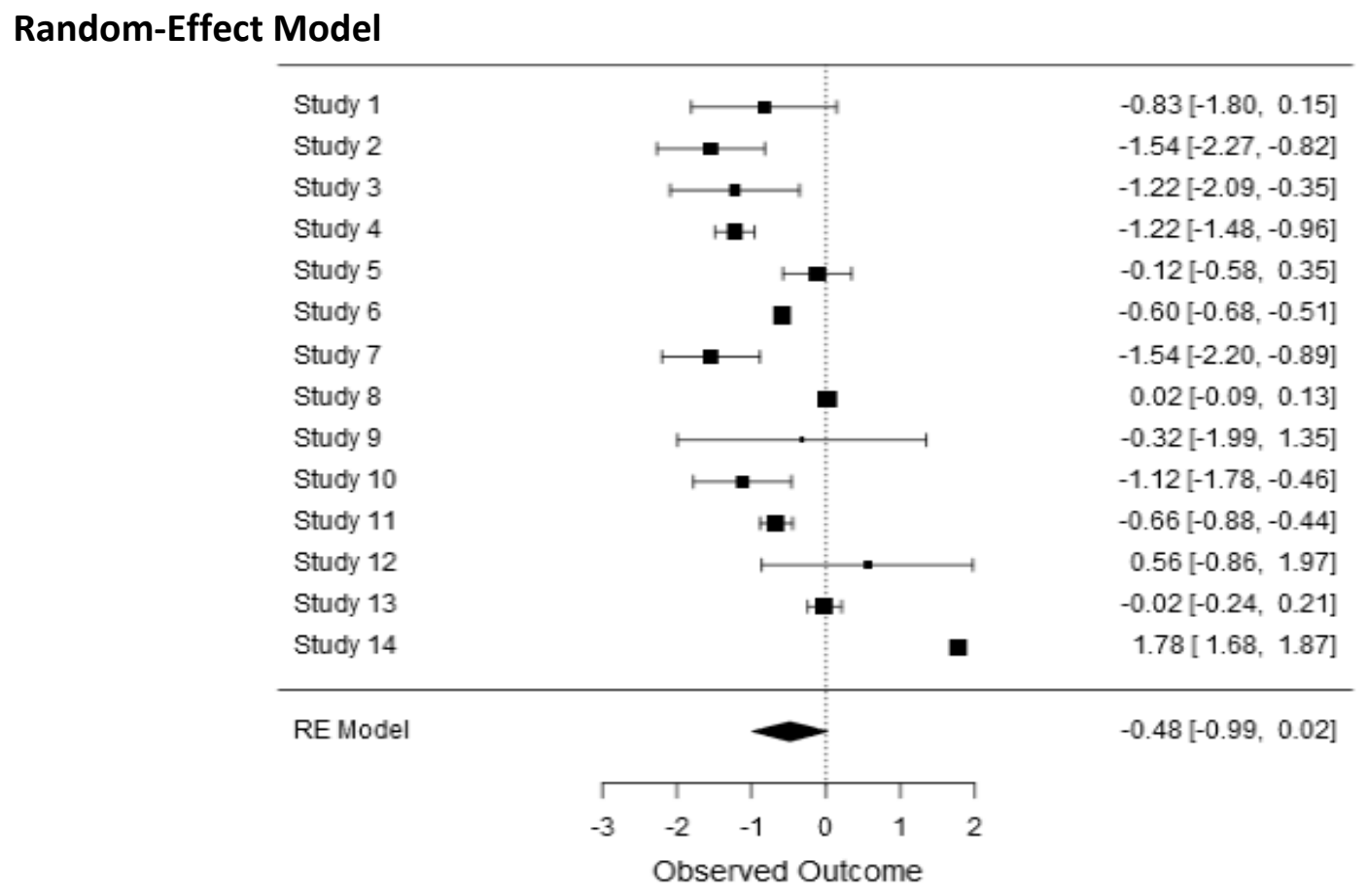

1. $I^{2}(\%)=98.442, r^{2}=0.855, \mathrm{AIC}=39.186$

2. $\mathrm{BIC}=40.641$, AICc $=42.186$, Omnibus test of Model $=0.311(\mathrm{df}=1, \mathrm{p}$-value $=0.047)$

3. Test of Residual Heterogeneity $=1721.924$ (df $=12, p$-value $=<.001)$

Figure 4: Forest Plot

Forest plot from Figure 4 showing that the results of 14 studies examining the potential relationships of demographic, education, and price (income) towards medical health insurance and takaful demands. The figure shows the relative risk of $95 \%$ confidence intervals for each study based on random-effects model which concluded that the effects of demographic, education and price (income) have significant $(\mathrm{Cl}=-0.99$ to 0.02 ) association on medical health insurance and takaful demand. Among of 14 studies, only two studies were identified did not statistically significant on medical health insurance which are Study $9(\mathrm{Cl}=-1.99$ to 1.35$)$ and Study $12(-0.86$ to 1.97). Moreover, $R^{2}=98.442 \%$ of this study is higher than the recommended value of $50 \%$ which means the studies are varied each other (heterogeneity of effect size) and suitable for the use of random effect method. This assessment is supported by the test of residual heterogeneity which is highly significant $(Q=$ 1721.924, $\mathrm{df}=12$, $\mathrm{p}$-value $<0.001$ ). 


\section{Publication Bias using Funnel Plot}

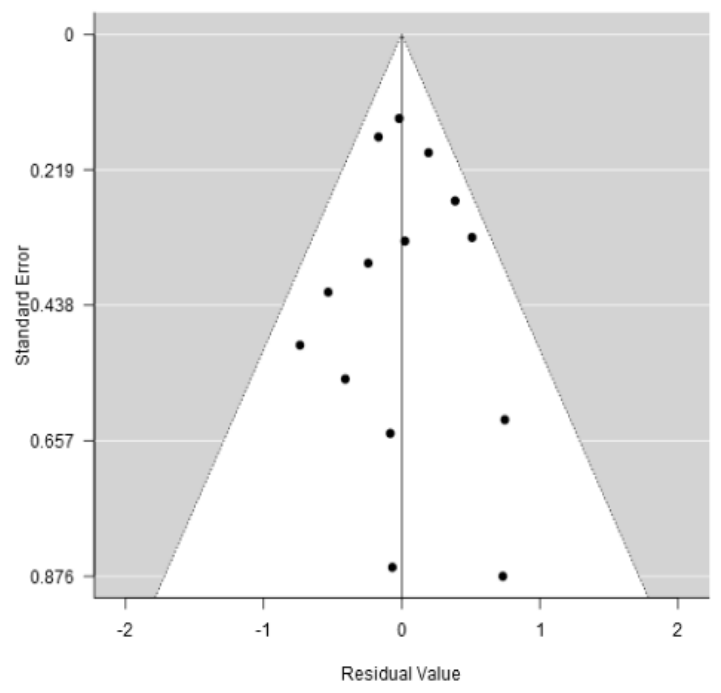

Figure 5: Funnel Plot

Funnel plot from Figure 5 showing the result for each study used in the current study. It was used as a check for bias in meta-analysis results. In other words, the funnel plot should be adopted in metaanalysis to avoid the detrimental problem of bias results. According to Kossemier, Tran \& Varacek (2017), the visual of funnel plot is recognized as a prominent tool for determining the publication bias result compared to Trim-Fill and Fail-Safe $\mathrm{N}$ plot. As is shown, it compares between standard error and residual value and all points are lie in a triangle $95 \%$ of the time which means no publication bias existed in the study.

\section{Conclusion}

This research paper identifies and determines the factor of the demand for Medical Health Insurance and Takaful among the public in Malaysia. The research focuses on the public in Malaysia especially on the determinant of demand for Medical Health Insurance and Takaful. The main factor of Effecting the Medical Health Insurance and Takaful is a demographic factor. Under the demographic factor, the researcher finds out the age and gender.

The age was positively related to awareness of Medical Health Insurance and Takaful. The younger generation less awareness about Medical Health Insurance and Takaful while the older generation more aware of Medical Health Insurance and Takaful, whereas increasing the age will increase awareness Medical Health Insurance and Takaful. The result suggests that for the gender factor, female have higher demand in buying Medical Health Insurance and Takaful rather than male. The price factor also gives a positive impact on the demand for Medical Health Insurance and Takaful. People with a higher income have the higher demand for the insurance because they can afford the insurance premium than people with lower income.

Demand for Medical Health Insurance and Takaful higher for people with higher education because they are more aware of the importance of having insurance. Government plays an important role in increasing the awareness of the public about Medical Health Insurance and Takaful. The public need 
INTERNATIONAL JOURNAL OF ACADEMIC RESEARCH IN BUSINESS AND SOCIAL SCIENCES

Vol. 9, No. 1, Jan, 2019, E-ISSN: 2222-6990 ㄷ 2019 HRMARS

to know how Health Insurance can help to ease their burden. Researcher's recommendation for future research is to use public in Malaysia as sample for research instead of just focusing only in one state

\section{References}

Kansra, P., \& Pathania, G. (2012). A study of factor affecting the demand for health insurance in Punjab. Journal of Management and Science, 2(4), 1-10.

O'Connor, G. E. (2015). The impact of insurance coverage on consumer utilization of health services: An exploratory study. International Journal of Bank Marketing, 33(3), 276-297.

Flynn, K. (2016). Financial fraud in the private health insurance sector in Australia: Perspectives from the industry. Journal of Financial Crime, 23(1), 143-158.

Sindecharak, T., \& Prasarkul, P. (2010). Factors determining having secondary health insurance among Thai population: evidence from KDSS. Journal of Population and Social Studies, 19(1), 37-58.

Handel, B. R., \& Kolstad, J. T. (2015). Health insurance for" humans": Information frictions, plan choice, and consumer welfare. American Economic Review, 105(8), 2449-2500.

Htay, S. N. N., Sadzali, N. S., \& Amin, H. (2015). An analysis of the viability of micro health takaful in Malaysia. Qualitative Research in Financial Markets, 7(1), 37-71.

Bailey, J., \& Webber, D. (2017). The political roots of health insurance benefit mandates. Journal of Economic Studies, 44(2), 170-182.

Piulachs, X., Alemany, R., \& Guillen, M. (2017). Emergency care usage and longevity have opposite effects on health insurance rates. Kybernetes, 46(1), 102-113.

Gupta, H. (2007). The role of insurance in health care management in India. International Journal of Health Care Quality Assurance, 20(5), 379-391.

Quaye, R. K. (2007). Health care financing in Uganda: the role of social health insurance. International journal of health care quality assurance, 20(3), 232-239.

Husniyah, A. R., Norhasmah, S., \& Amim, O. M. (2017). Assessing Predictors for Health Insurance Purchase Among Malaysian Public Sector Employees. In Regional Studies on Economic Growth, Financial Economics and Management (pp. 91-107). Springer, Cham.

Abu-Bakar, A., Samsudin, S., \& Regupathi, A. (2016). The effect of health insurance on health care utilization: evidence from Malaysia. In International Soft Science Conference.

Jones, G. (2012). Moral hazard and the impact of private health insurance on the utilisation of health care in Malaysia. Jurnal Ekonomi Malaysia, 46(2), 159-175.

Abdullah, L., \& Rahman, M. N. A. (2012). Employee likelihood of purchasing health insurance using fuzzy inference system. International Journal of Computer Science Issues (IJCSI), 9(1), 112.

Samsudin, S., Abu-Bakar, A., Regupathi, A., \& Aljunid, S. M. (2016). Does Health Insurance Ownership Determine Access and Frequency of Hospitalization? Evidence from the Two-part Poisson Model. International Journal of Economics and Financial Issues, 6(7S), 21-26.

Avraham, R., Dafny, L. S., \& Schanzenbach, M. M. (2010). The impact of tort reform on employersponsored health insurance premiums. The Journal of Law, Economics, \& Organization, 28(4), 657-686. 
INTERNATIONAL JOURNAL OF ACADEMIC RESEARCH IN BUSINESS AND SOCIAL SCIENCES

Vol. 9, No. 1, Jan, 2019, E-ISSN: 2222-6990 ㄷ 2019 HRMARS

Onwujekwe, O., \& Uzochukwu, B. (2005). Socio-economic and geographic differentials in costs and payment strategies for primary healthcare services in Southeast Nigeria. Health policy, 71(3), 383-397.

Loewenstein, G., Friedman, J. Y., McGill, B., Ahmad, S., Linck, S., Sinkula, S., ... \& Madrian, B. C. (2013). Consumers' misunderstanding of health insurance. Journal of Health Economics, 32(5), 850862.

Abdul Rahman, Z., \& Mohd Daud, N. (2010). Adverse selection and its consequences on medical and health insurance and takaful in Malaysia. Humanomics, 26(4), 264-283.

Spaan, E., Mathijssen, J., Tromp, N., McBain, F., Have, A. T., \& Baltussen, R. (2012). The impact of health insurance in Africa and Asia: a systematic review. Bulletin of the World Health Organization, 90, 685-692.

Schueler, K. M., Chu, P. W., \& Smith-Bindman, R. (2008). Factors associated with mammography utilization: a systematic quantitative review of the literature. Journal of women's health, 17(9), 1477-1498.

Adewole, D. A., Adebayo, A. M., Udeh, E. I., Shaahu, V. N., \& Dairo, M. D. (2015). Payment for health care and perception of the national health insurance scheme in a rural area in Southwest Nigeria. The American journal of tropical medicine and hygiene, 93(3), 648-654.

Mohammed, S., Sambo, M. N., \& Dong, H. (2011). Understanding client satisfaction with a health insurance scheme in Nigeria: factors and enrollees experiences. Health Research Policy and Systems, 9(1), 20.

Odeyemi, I. A. (2014). Community-based health insurance programmes and the national health insurance scheme of Nigeria: challenges to uptake and integration. International journal for equity in health, 13(1), 20.

Barakah, D. M., \& Alsaleh, S. A. (2011). The cooperative insurance in Saudi Arabia: A nucleus to health reform policy. In Proceedings of the International Conference on Information and Finance, Singapore (Vol. 21).

Dror, D. M., Hossain, S. S., Majumdar, A., Koehlmoos, T. L. P., John, D., \& Panda, P. K. (2016). What factors affect voluntary uptake of community-based health insurance schemes in low-and middle-income countries? A systematic review and meta-analysis. PLoS One, 11(8), e0160479.

World Health Organization. (2010). Impact of mutual health insurance on access to health care and financial risk protection in Rwanda (No. HSS/HSF/DP. E. 10.3). World Health Organization.

De Allegri, M., Kouyaté, B., Becher, H., Gbangou, A., Pokhrel, S., Sanon, M., \& Sauerborn, R. (2006). Understanding enrolment in community health insurance in sub-Saharan Africa: a populationbased case-control study in rural Burkina Faso. Bulletin of the World Health Organization, 84, 852-858.

Drechsler, D., \& Jutting, J. (2007). Different countries, different needs: the role of private health insurance in developing countries. Journal of Health Politics, Policy and Law, 32(3), 497-534.

Holly Wang, H., Huang, S., Zhang, L., Rozelle, S., \& Yan, Y. (2010). A comparison of rural and urban healthcare consumption and health insurance. China Agricultural Economic Review, 2(2), 212227. 
INTERNATIONAL JOURNAL OF ACADEMIC RESEARCH IN BUSINESS AND SOCIAL SCIENCES

Vol. 9, No. 1, Jan, 2019, E-ISSN: 2222-6990 ㄷ 2019 HRMARS

Fang, K., Shia, B. C., \& Ma, S. (2012). Health insurance coverage, medical expenditure and coping strategy: evidence from Taiwan. BMC health services research, 12(1), 442.

Fang, K., Shia, B. C., \& Ma, S. (2012). Health insurance coverage, medical expenditure and coping strategy: evidence from Taiwan. BMC health services research, 12(1), 442.

Hidalgo, H., Chipulu, M., \& Ojiako, U. (2013). Risk segmentation in Chilean social health insurance. International journal of health care quality assurance, 26(7), 666-681.

Jeong, H. S. (2011). Korea's National Health Insurance-lessons from the past three decades. Health Affairs, 30(1), 136-144.

Spaan, E., Mathijssen, J., Tromp, N., McBain, F., Have, A. T., \& Baltussen, R. (2012). The impact of health insurance in Africa and Asia: a systematic review. Bulletin of the World Health Organization, 90, 685-692.

Preker, A. S., Carrin, G., Dror, D., Jakab, M., Hsiao, W., \& Arhin-Tenkorang, D. (2002). Effectiveness of community health financing in meeting the cost of illness. Bulletin of the World Health Organization, 80, 143-150.

Tanko, G. I., Harun, A., Gorondutse, A. H., \& Salihu, A. A. (2015). Investigating the Impact of Community Based Health Insurance Scheme among the Rural Dwellers of Sokoto State Nigeria. Mediterranean Journal of Social Sciences, 6(1 S1), 145.

Nsiah-Boateng, E., \& Aikins, M. (2013). Performance assessment of Ga district mutual health insurance scheme, greater Accra region, Ghana. Value in health regional issues, 2(2), 300305.

Emamgholipour, S., Arab, M., \& Ebrahimzadeh, J. (2016). Demand for Self-Employed Health Insurance. The Eurasian journal of medicine, 48(3), 172.

Chomi, E. N., Mujinja, P. G., Enemark, U., Hansen, K., \& Kiwara, A. D. (2014). Health care seeking behaviour and utilisation in a multiple health insurance system: does insurance affiliation matter? International journal for equity in health, 13(1), 25.

Nosratnejad, S., Rashidian, A., Sari, A. A., \& Moradi, N. (2017). Willingness to pay for complementary health care insurance in Iran. Iranian journal of public health, 46(9), 1247.

Cameron, A. C., Trivedi, P. K., Milne, F., \& Piggott, J. (1988). A microeconometric model of the demand for health care and health insurance in Australia. The Review of economic studies, 55(1), 85106.

Feldstein, M. S. (1973). The welfare loss of excess health insurance. Journal of Political Economy, 81(2, Part 1), 251-280.

Hurd, M. D., \& McGarry, K. (1997). Medical insurance and the use of health care services by the elderly. Journal of Health Economics, 16(2), 129-154.

Baker, D. W., Sudano, J. J., Albert, J. M., Borawski, E. A., \& Dor, A. (2001). Lack of health insurance and decline in overall health in late middle age. New England Journal of Medicine, 345(15), 1106-1112.

Lillie-Blanton, M., \& Hoffman, C. (2005). The role of health insurance coverage in reducing racial/ethnic disparities in health care. Health affairs, 24(2), 398-408.

Liu, S., \& Chollet, D. (2006). Price and income elasticity of the demand for health insurance and health care services: a critical review of the literature. Mathematica Policy Research. 
INTERNATIONAL JOURNAL OF ACADEMIC RESEARCH IN BUSINESS AND SOCIAL SCIENCES

Vol. 9, No. 1, Jan, 2019, E-ISSN: 2222-6990 @ 2019 HRMARS

Nakagawa, S., Noble, D. W., Senior, A. M., \& Lagisz, M. (2017). Meta-evaluation of meta-analysis: ten appraisal questions for biologists. BMC biology, 15(1), 18.

Protogerou, C., Johnson, B. T., \& Hagger, M. S. (2018). An integrated model of condom use in SubSaharan African youth: A meta-analysis. Health Psychology, 37(6), 586.

Kooij, D. T. A. M., Kanfer, R., Betts, M., \& Rudolph, C. W. (2018). Future time perspective: A systematic review and meta-analysis. The Journal of applied psychology.

Tzabbar, D., Tzafrir, S., \& Baruch, Y. (2017). A bridge over troubled water: Replication, integration and extension of the relationship between HRM practices and organizational performance using moderating meta-analysis. Human Resource Management Review, 27(1), 134-148.

Fan, H., Xu, J., Cai, Z., He, J., \& Fan, X. (2017). Homework and students' achievement in math and science: A 30-year meta-analysis, 1986-2015. Educational Research Review, 20, 35-54.

Ngamaba, K. H., Panagioti, M., \& Armitage, C. J. (2017). Income inequality and subjective well-being: a systematic review and meta-analysis. Quality of Life Research, 1-20.

Ones, D. S., Viswesvaran, C., \& Schmidt, F. L. (2017). Realizing the full potential of psychometric metaanalysis for a cumulative science and practice of human resource management. Human Resource Management Review, 27(1), 201-215.

Kim, Y., \& Peterson, R. A. (2017). A Meta-analysis of Online Trust Relationships in Ecommerce. Journal of Interactive Marketing, 38, 44-54.

Viechtbauer, W. (2010). Conducting meta-analyses in R with the metafor package. J Stat Softw, 36(3), 1-48.

Hedges LV, Olkin, I. (1985). Statistical Methods for Meta-Analysis. Academic Press, San Diego, CA.

Heck, D. W., Gronau, Q. F., \& Wagenmakers, E. J. (2017). metaBMA: Bayesian model averaging for random and fixed effects meta-analysis.

Guolo, A., \& Varin, C. (2017). Random-effects meta-analysis: the number of studies matters. Statistical methods in medical research, 26(3), 1500-1518.

Higgins, J. P. T., \& Green, S. (2011). Cochrane Handbook for Systematic Reviews of Interventions. London: The Cochrane Collaboration.

Kossmeier, M., Tran, U. S., \& Voracek, M. (2017, July). Visual funnel plot inference for meta-analysis. In The R User Conference, useR! 2017 July 4-7 2017 Brussels, Belgium (p. 113).

Afthanorhan, A., Awang, Z., \& Fazella, S. (2017a). Perception of Tourism Impact and Support Tourism Development in Terengganu, Malaysia. Social Sciences, 6(3), 106.

Awang, Z., Afthanorhan, A., Mohamad, M., \& Asri, M. A. M. (2015). An evaluation of measurement model for medical tourism research: the confirmatory factor analysis approach. International Journal of Tourism Policy, 6(1), 29-45.

Afthanorhan, A., Awang, Z., \& Fazella, S. (2017b). Developing the patients' loyalty model for medical tourism industry: the case of Malaysia. International Journal of Society Systems Science, 9(2), 139-164. 